\title{
AKTYWNOŚĆ CESARZA W KONTEKŚCIE SPORÓW CHRYSTOLOGICZNYCH W BIZANCJUM W VII WIEKU
}

W VII w. za cesarza Herakliusza I (610-641) Bizancjum stanęło w obliczu wielkiego niebezpieczeństwa. $Z$ zachodu i północy zagrożenie stanowili Awarowie i Słowianie, natomiast ze wschodu - Persowie. W latach 613-620 zajęli oni nie tylko Syrię i Palestynę, lecz także Egipt oraz Armenię. Ludność miejscowa $\mathrm{w}$ większości nie przejawiała entuzjazmu w stawianiu oporu najeźdźcom, wręcz nawet szukała korzyści z tej sytuacji. W Egipcie ludność miejscowa, w większości monofizycka, nie stawiała Persom żadnego oporu. Za rządów perskich monofizyci Syrii i Egiptu cieszyli się poparciem władzy, natomiast zwolennicy Chalcedonu byli prześladowani. We wschodnich prowincjach monofizyci zostali więc umocnieni. W tym okresie także na Zachodzie cesarstwo zetknęło się z różnymi problemami. Hiszpania wpadła w ręce Wizygotów, Italia zaś była stale zagrożona przez Longobardów. Ponadto od długiego czasu niebezpieczeństwo dla Cesarstwa stanowili Słowianie i Awarowie ${ }^{1}$. W nieco późniejszym zaś okresie z Pustyni Arabskiej zagrożenie nieśli Arabowie².

W tej bardzo niebezpiecznej sytuacji cesarz za wszelką cenę pragnął utrzymać lojalność prowincji promonofizyckich, które były jeszcze pod jego wpływem. Należało więc dojść z monofizytami do porozumienia na płaszczyźnie religijnej. Skutkiem kompromisu miało być powszechne uznanie wspólnej doktryny teologicznej. Ponieważ cesarz zaangażował się w kontrowersje

* Dr Oleksandr Kashchuk - adiunkt w Katedrze Historii Wieków Średnich i Bizancjum na Wydziale Historii Uniwersytetu im. Iwana Franki we Lwowie oraz w Katedrze Teologii na Wydziale Filozoficzno-Teologicznym Ukraińskiego Katolickiego Uniwersytetu we Lwowie; e-mail: oleksandr@wp.pl.

${ }^{1}$ Por. A.N. Stratos, Byzantium in the Seventh Century, t. 1: 602-634, thum. M. Ogilvie-Grant, Amsterdam 1968, 107-123 i 284-286; W.E. Kaegi, Heraclius: Emperor of Byzantium, Cambridge 2003, 58-99 i 263; J.F. Haldon, Byzantium in the Seventh Century. The Transformation of a Culture, Cambridge 1997, 42-47; G. Dagron, Kościót bizantyński i chrześcijaństwo bizantyńskie między najazdami a ikonoklazmem (VII wiek - poczqtek VIII wieku), w: Historia chrześcijaństwa. Religia-kultura-polityka, t. 4: Biskupi, mnisi i cesarze 610-1054, red. J.M. Mayer-Ch.I.L. Pietri - A. Vauchez - M. Venard, red. wydania polskiego J. Kłoczowski, Warszawa 1999, 18-29.

2 Por. A.N. Stratos, Byzantium in the Seventh Century, t. 2: 634-641, thum. H.T. Hionides, Amsterdam 1972, 40-116; Haldon, Byzantium in the Seventh Century, s. 54-55; Dagron, Kościót bizantyński, s. 30-32. 
chrystologiczne, oprócz dyskusji doktrynalnych pośrednio ożywiły się dyskusje ideologiczne, dotyczące roli cesarza w Kościele. Jednak, co ciekawe, w tym czasie nie powstał żaden traktat na temat ideologii władzy. Generalnie bowiem okres od śmierci cesarza Herakliusza do intronizacji Bazylego I (641-867) pozostawił bardzo mało pisemnych świadectw dotyczących myśli społeczno-politycznej oraz ideologii władzy ${ }^{3}$. Te treści można wydobyć m.in. ze źródeł o charakterze historyczno-teologicznym ${ }^{4}$, które dotyczą sporów monoteletycznych.

Na podstawie analizy źródeł można stwierdzić, że w Bizancjum w VII w. istniały zasadniczo dwie sformułowane $\mathrm{w}$ wiekach poprzednich ideologie, dotyczące zakresu władzy cesarskiej w odniesieniu do Kościoła, które ze względu na ich orientację można określić mianem procesarskiej oraz prorzymskiej. Różniły się one co do zakresu uprawnień przyznawanych cesarzowi w stosunku do Kościoła. Niemniej jednak każda z nich podkreślała znaczenie stanowiska cesarza $w$ kwestiach religijnych. Celem niniejszego artykułu jest przedstawienie aktywności cesarza $\mathrm{w}$ sferze sporów chrystologicznych w VII w. oraz ideologii, która warunkowała jego stanowisko. Artykuł jest podzielony na trzy czesści. W pierwszej zostanie przedstawiony charakter udziału cesarza w dążeniu do kompromisu, w drugiej - podłoże ideologiczne jego działania, a w części trzeciej zostanie ukazany sposób recepcji procesarskiej ideologii władzy w Kościele bizantyńskim w tym okresie.

1. Charakter aktywności cesarza. Cesarz Herakliusz był bardzo zainteresowany doprowadzeniem do kompromisu między chrześcijanami uznającymi Sobór Chalcedoński a monofizytami, aby w ten sposób usunąć napięcie polityczne wywołane przez nieporozumienia teologiczne i tym samym zjednoczyć Cesarstwo w obliczu wroga. Jedna wiara miała w przekonaniu cesarza zrównoważyć brak jednej, rozumianej etnicznie narodowości ${ }^{5}$. W tej dziedzinie cesarz współpracował z patriarchą Konstantynopola Sergiuszem (610-638) który był zagorzałym zwolennikiem kompromisu teologicznego. Z inicjatywy patriarchy Sergiusza ok. roku 616 zapoczątkowano negocjacje zmierzające do porozumienia z monofizytami. Chodziło o uzyskanie formuły wiary, która uznałaby istnienie w Chrystusie dwóch natur, lecz tylko jednego działania ${ }^{7}$.

${ }^{3}$ Social and Political Thought in Byzantium from Justinian I to the last Palaeologus. Passages from Byzantine writers and documents, transl. with an introduction and notes by E. Barker, Oxford 1957, 81.

${ }^{4}$ Por. A. Pertusi, Il pensiero politico bizantino, Il mondo medievale 6, Bologna 1990, 65.

${ }^{5}$ Por. Stratos, Byzantium, t. 1, s. 299; Kaegi, Heraclius: Emperor of Byzantium, s. 210.

${ }^{6} \mathrm{Na}$ temat stosunków między cesarzem Herakliuszem a patriarchą Sergiuszem, por. Kaegi, Heraclius: Emperor of Byzantium, s. 60.

${ }^{7}$ Por. Stratos, Byzantium, t. 1, s. 287-288; Haldon, Byzantium in the Seventh Century, s. 48-49; Dagron, Kościót bizantyński, s. 42; H. Rahner, Kościót i państwo we wczesnym chrześcijaństwie, tłum. M. Radożycka - J. Radożycki, Warszawa 1986, 226-227; B. Flusin, Tryumf chreścijaństwa i określenie prawowierności, w: Świat Bizancjum, t. 1: Cesarstwo wschodniorzymskie 330 - 641, red. C. Morrisson, thum. A. Graboń, Kraków 2007, 92-94. 
Negocjacje prowadzono z wielkim trudem. Patriarcha Sergiusz działał przede wszystkim za pomocą rozległej korespondencji. Natomiast cesarz Herakliusz osobiście przeprowadził kilka spotkań w Armenii oraz Syrii. Po odzyskaniu Egiptu od Persów w 629 r. mianował on Cyrusa (631-641) patriarchą Aleksandrii. Z polecenia cesarza nowy patriarcha Aleksandrii zaczął zmierzać do kompromisu z Koptami ${ }^{8}$.

W 633 r. w Aleksandrii przyjęto dokument zjednoczeniowy, tzw. Dziewięć Rozdziałów, który miał doprowadzić do pojednania między egipskimi monofizytami a zwolennikami Chalcedonu na podstawie formuły monoener-

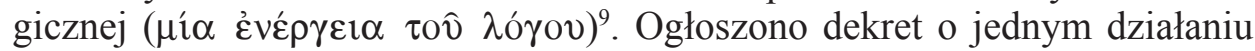
w Chrystusie oraz o Jego naturze ludzkiej i boskiej ${ }^{10}$. Patriarcha Konstantynopola Sergiusz w 633 r. zaaprobował tę naukę i potwierdził na synodzie ${ }^{11}$. Napisał również list do papieża Honoriusza (625-638) i uzyskał odpowiedź, którą uznał za pozytywną ${ }^{12}$.

Mnich Sofroniusz z Jerozolimy (ok. 560-638; patriarcha Jerozolimy 634638) wyraził jednak sprzeciw wobec tych postanowień. Sformułował on też tezę o dwóch działaniach, które współpracują na zasadzie jedności w Chrystusie działającym $^{13}$. Opozycja wobec monoenergetyzmu wzrastała ${ }^{14}$. W tej sytuacji patriarcha Sergiusz zadecydował, że trzeba ogłosić cesarskie wyznanie wiary, które powinno obowiązywać wszystkich mieszkańców Imperium. W tym celu na przełomie roku 634/635 ułożył Ekthesis wiary w imieniu cesarza Herakliusza $^{15}$. We współpracy z Cyrusem Aleksandryjskim przekonał cesarza, aby ogłosił nowe wyznanie dla całego Imperium. W ten sposób Ekthesis zostało ogłoszone w październiku roku $638^{16}$. Tekst dokumentu zawiera wyrażenie: ,jedna

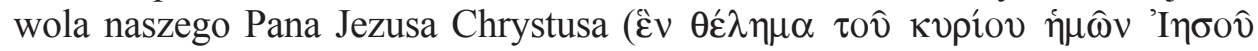

${ }^{8}$ Por. Stratos, Byzantium, t. 1, s. 286-298; Kaegi, Heraclius: Emperor of Byzantium, s. 213-214 i 216.

${ }^{9}$ Por. Satisfactio facta inter Cyrum et eos qui erant ex parte Theodosianorum, Mansi XI 564C 568B. Zob. Concilium Lateranense a. 649 celebratum, ed. R. Riedinger, ACO II/1, Berlin 1984, 134, 19; Vita ac certamen Sancti Maximi Confessoris IX, PG 90, 77C-D. Zob. też Stratos, Byzantium, t. 1, s. 298.

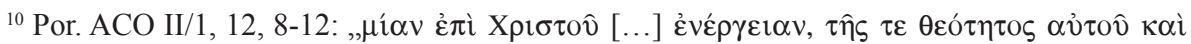

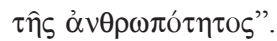

${ }^{11}$ Por. ACO II/1, 12, 13-14.

${ }^{12}$ Por. Diffloratio ex epistola s. Maximi ad Marinum presbyterum, Mansi X 689. Zob. Stratos, Byzantium, t. 1, s. 300-301.

${ }^{13}$ Por. Concilium Alexandrinum (633), Mansi X 607A; Concilium Constantinopolitanum III (680), Actio XII, Mansi XI 533.

${ }^{14}$ Por. Stratos, Byzantium, t. 1, s. 301-304.

${ }^{15}$ Por. ACO II/1, 16, 21-33; Concilium Constantinopolitanum III (680), Actio XIV, Mansi XI 606B-C. Zob. Dagron, Kościót bizantyński, s. 43; Stratos, Byzantium, t. 1, s. 301; tenże, Byzantium, t. 2 , s. 142 .

${ }^{16}$ Expositio orthodoxae fidei (Ecthesis), ed. R. Riedinger, w: ACO II/1, 156, 27 - 162, 13 (secretarius III). Por. Kaegi, Heraclius: Emperor of Byzantium, s. 269-271. O przyczynach zwlekania z podpisaniem dokumentu przez kilka lat zob. Stratos, Byzantium, t. 2, s. 143. 


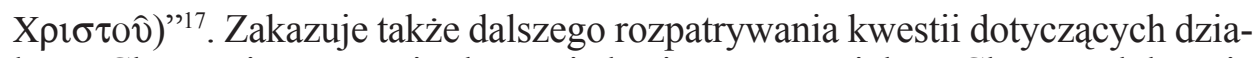
łań w Chrystusie oraz stwierdza, że jeden i ten sam wcielony Chrystus dokonuje dzieł Bożych i dzieł ludzkich ${ }^{18}$. Chociaż potwierdzono istnienie dwóch natur w Chrystusie, to jednak w imię kompromisu z monofizytami dodano, że od momentu zjednoczenia natur w Chrystusie istniało tylko jedno Bosko-ludzkie działanie. Był to więc monoteletyczny wykład wiary wydany i podpisany przez cesarza, który miał obowiązywać chrześcijan w całym Cesarstwie.

Patriarcha Sergiusz potwierdził Ekthesis na pseudo-soborze w 638 roku $^{19}$. Dokument aprobowali także: Cyrus Aleksandryjski, Sergiusz, biskup Joppy, który pełnił obowiązki patriarchy Jerozolimy, oraz patriarcha Antiochii Makariusz $^{20}$. Po śmierci Sergiusza patriarchą Konstantynopola został Pyrrus (638$641 ; \uparrow 654)$. Na przełomie roku $638 / 639$ zwołał on synod do Konstantynopola, na którym ponownie aprobowano Ekthesi ${ }^{21}$. W ten sposób cesarska interwencja w kwestie wiary otrzymała silną legitymizację ze strony hierarchów Kościoła obszaru bizantyńskiego.

Jednak w zaistniałej sytuacji zaczęło się pogłębiać napięcie między Konstantynopolem a Stolicą Piotrową. Papież Seweryn (640) zwołał synod do Rzymu w 640 r., na którym potępiono dogmatyczne treści Ekthesis ${ }^{22}$. W tym samym roku synod zebrany w Rzymie już za papieża Jana IV (640-642) potępił monoteletyzm ${ }^{23}$, a w 641 r. na kolejnym synodzie rzymskim ekskomunikowano Sergiusza, Cyrusa i Pyrrusa ${ }^{24}$. W roku 641 Pyrrusa, który opuścił Konstantynopol, zastąpił Paweł (641-653) ${ }^{25}$, a papieżem w 642 r. został Teodor (642-649), który na zwołanym przez siebie synodzie potępił po raz kolejny dogmatyczne treści Ekthesis ${ }^{26}$. Papież Teodor zabiegał też u następcy Herakliusza, Konstansa II (641-668), o odwołanie Ekthesis ${ }^{27}$. Napięcie między Rzymem a Konstantynopolem wynikało więc nie tylko z różnic teologicznych, lecz także z różnic dotyczących uprawnień cesarza w kwestiach religijnych.

${ }^{17}$ Expositio orthodoxae fidei (Ecthesis), ACO II/1, 160, 25-26. Por. Dagron, Kościót bizantyński, s. 43.

${ }^{18}$ Expositio orthodoxae fidei (Ecthesis), ACO II/1, 160, 1-19.

${ }^{19}$ Por. Concilium Constantinopolitanum (638), Mansi X 677E - 680A; Concilium Lateranense Romanum (649), Excerpta gestorum pro Ecthesi a Sergio, Mansi X 1000A - 1001B. Zob. ACO II/1, $16,25-27$.

${ }^{20}$ Por. Stratos, Byzantium, t. 2, s. 144.

${ }^{21}$ Por. Concilium Lateranense Romanum (649), Excerpta gestorum a Pyrrho pro Ecthesi, Mansi X 1001C - 1004B; Ad Concilium Alexandrinum (633), Constantinopolitana Pyrrhi, Mansi X 607B. Zob. Stratos, Byzantium, t. 2, s. 145-146.

${ }^{22}$ Por. Cncilium Romanum (640), Mansi X 679A - 680D.

${ }^{23}$ Por. tamże, Mansi X 697C-D.

${ }^{24}$ Por. Ad Concilium Alexandrinum (633), Romana Joannis, Mansi X 608E.

${ }^{25}$ Por. Stratos, Byzantium, t. 2, s. 194-198; tenże, Byzantium in the Seventh Century, t. 3: 642668, thum. H.T. Hionides, Amsterdam 1975, 128.

${ }^{26}$ Por. tenże, Byzantium, t. 3, s. 85-86.

${ }^{27}$ Por. Concilium Lateranense Romanum (649), Mansi X 878D. Zob. Stratos, Byzantium, t. 3, s. $60-61$ i $87-89$. 
Chodziło bowiem o aprobowanie doktryny promulgowanej i propagowanej przez cesarza.

W latach 40. VII w. monoteletyzm miał już niemało zwolenników. Chociaż prawie powszechnie był on odrzucany na łacińskim Zachodzie (w Rzymie i w Afryce), gdzie aktywnie działał Maksym Wyznawca, to jednak w Syrii i Palestynie był akceptowany. Prawdopodobnie to było przyczyna, z powodu której cesarz Konstans nie zamierzał odwoływać Ekthesis ${ }^{28}$. Jak się jednak później okazało, optymizm cesarza był iluzoryczny, ponieważ monoteletyzm nie osłabił wrogości miejscowej ludności, w większości monofizytów, wobec Bizantyńczyków ${ }^{29}$.

Tymczasem pod koniec lat 40. VII w. obszary Cesarstwa, ze względu na które wspierano monoteletyzm, zostały utracone. W latach 633-645 Arabowie podbili bowiem Persję, Palestynę, Syrię, Mezopotamię oraz Egipt. Miejscowa ludność nie przejawiała zbytniej aktywności w obronie swoich krajów, wręcz przeciwnie, mogła nawet wyrażać obojętność albo nawet entuzjazm w obliczu zaistniałej sytuacji ${ }^{30}$. Ponieważ polityka propagowania monoteletyzmu nie przyniosła oczekiwanych owoców, należało zatem wyciszyć kontrowersje, które ona wywołała. Patriarcha Paweł przekonał cesarza Konstansa II do wydania edyktu o wierze, tzw. Typos, który został promulgowany w 648 roku $^{31}$. Typos nie poruszał problemów doktrynalnych, lecz zakazywał dyskusji o tym, czy Chrystus miał dwie wole czy też jedną, jak również zabraniał dysput na temat Jego jednego lub dwóch działań ${ }^{32}$. W ten sposób cesarz ponownie wmieszał się w dogmatyczne sprawy Kościoły, zakazując dyskusji na powyższe kwestie. Typos nie rozwiązał jednak kontrowersji, lecz pozostawił ją w dwuznacznym zawieszeniu. Świadczy to o tym, że w gruncie rzeczy cesarzowi nie chodziło o precyzyjne sformułowanie doktryny i że sami zwolennicy monoteletyzmu w zasadzie nimi nie byli. Potwierdza to pozycja procesarskiego biskupa Teodozjusza, który przekonywał Maksyma Wyznawcę, że Typos chociaż jest złem, jest jednak konieczny ze względu na pokój w Cesarstwie ${ }^{33}$.

${ }^{28}$ Monoteletyzm ogarnął prawie cały Wschód i części Zachodu. Por. Vita ac certamen Sancti Maximi Confessoris VII, PG 90, 76A. Zob. Haldon, Byzantium in the Seventh Century, s. 56. Jak się później okaże, optymizm był iluzoryczny. Por. Stratos, Byzantium, t. 1, s. 299 i 302-303; tenże, Byzantium, t. 3, s. 94-95.

${ }^{29}$ Por. Stratos, Byzantium, t. 1, s. 299 i 302-303; tenże, Byzantium, t. 2, s. 127-133 i 142; tenże, Byzantium, t. 3, s. 94-95.

${ }^{30}$ Por. tenże, Byzantium, t. 2, s. 40-116.

${ }^{31}$ Por. Typus (Constantis imperatoris), ed. R. Riedinger, w: ACO II/1, 206, 31-210, 15 (secretarius IV). Zob. Stratos, Byzantium, t. 3, s. 95-97.

${ }^{32}$ Por. ACO II/1, 18, 14-18. Por. Dagron, Kościót bizantyński, s. 44; Stratos, Byzantium, t. 3 , s. 95-96. Edykt zdaje się nie być stronniczy, dlatego spowodował także niezadowolenie monoteletów, ponieważ przez Typos w sposób pośredni został pozbawiony mocy prawnej także Ekthesis. Zob. Stratos, Byzantium, t. 3, s. 96.

${ }^{33}$ Por. Acta in primo exsilio seu dialogus Maximi cum Theodosio episcopo Caesareae in Bithynia

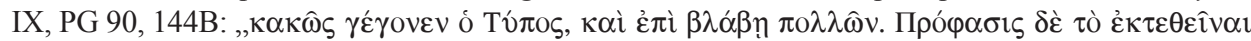


Kwestia monoteletyzmu została zawieszona prawdopodobnie w nadziei na odzyskanie utraconych ziem ${ }^{34}$. Jednak owo podporządkowanie zagadnień teologicznych aktualnej sytuacji militarno-politycznej Cesarstwa wzbudziło jeszcze większy niepokój, którego skutkiem był wzrost napięć religijnych ${ }^{35}$. W 648 r. w Rzymie na synodzie zwołanym przez papieża Teodora zostali potępieni patriarchowie Konstantynopola Paweł i Pyrrus oraz monoteletyzm jako taki wraz z Typosem wydanym przez Konstansa ${ }^{36}$. Następny papież Marcin I (649-655) zwołał w roku 649 zgromadzenie biskupów na Lateranie ${ }^{37}$. Potępił Teodora - biskupa Pharan, Cyrusa - patriarchę Aleksandrii, Sergiusza - patriarchę Konstantynopola, jego następców, Pyrrusa i Pawła, oraz dwa monoteletyczne pisma, a mianowicie Ekthesis i Typos $^{38}$. Stronnictwo procesarskie nie miało jednak zamiaru tolerować papieskiego stanowiska w tym zakresie ${ }^{39}$. Egzarcha Teodor Kalliopas aresztował Marcina I w czerwcu $653 \mathrm{roku}^{40}$. Papieża traktowano jako zbrodniarza i wroga cesarza ${ }^{41}$. Marcin I nigdy jednak nie został oficjalnie obwiniony o zwołanie synodu w 649 r., lecz o to, że objął papieski tron bez zgody cesarza i że wsparł Olimpiusza, egzarchę Rawenny, który zbuntował się w 649 r. W marcu 654 r. papież został wysłany na Krym, gdzie zmarł we wrześniu $655 \mathrm{roku}^{42}$. Cesarz Konstans II pragnął w ten sposób

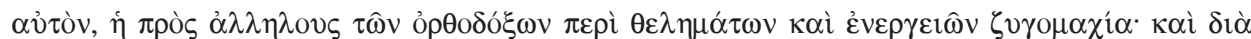

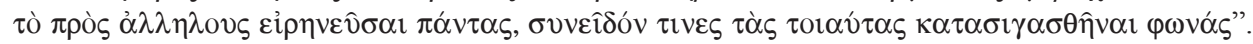

${ }^{34}$ Por. Haldon, Byzantium in the Seventh Century, s. 59; Stratos, Byzantium, t. 3, s. 94.

${ }^{35}$ Por. Martinus I Papa, Epistula 2 [Ad Constantem Imperatorem], PL 87, 142C: „ex quibus non exigua perturbation tandiu universam terram vexat; quod non solum pii populi scandalizentur, sed impii etiam barbari”.

${ }^{36}$ Por. Concilium Romanum (648), Mansi X 783B-C.

${ }^{37}$ Por. Martinus I Papa, Epistula 2 [Ad Amandum Episcopum Trajectensem], PL 87, 137C - 138A. Akta Synodu Laterańskiego są cennym źródłem dla poznania kontrowersji monoteletycznej. Oryginalnym językiem aktów synodalnych był język grecki. Tekst grecki służył jako baza dla tłumaczenia łacińskiego. Tłumaczenie tekstu na język łaciński zostało dokonane przez mnichów, którzy przybyli do Rzymu razem z Maksymem Wyznawca. Zob. A. Alexakis, Codex Parisinus Graecus 1115 and It's Archetypes, Dumbarton Oaks Studies 34, Washington 1996, 18-19.

${ }^{38}$ Por. ACO II/1, 380-382, 390 i 402. Zob. Martinus I Papa, Epistula 4 [Ad Ecclesiam Carthaginensem], PL 87, 150C-D; tenże, Epistula 5 [Ad Joannem Episcopum Philadelphiae], PL 87, 159C-D; tenże, Epistula 11 [Ad Ecclesiam Jerosolymitanam et Antiochenam], PL 87, 176B - 177A; tenże, Epistula 12 [Ad Paulum Thessalonicensem Episcopum], PL 87, 192A-B.

${ }^{39}$ Papież Marcin w liście do Amandusa, biskupa w Gallii (Epistula 2 [Ad Amandum episcopum], PL 87, 135A-B i 137A-B), czyni aluzję, że doznaje niepokoju od cesarza z powodu własnej nieugiętości. Por. tenże, Epistula 11 [Ad Ecclesiam Jerosolymitanam et Antiochenam], PL 87, 179B - 180A.

${ }^{40}$ Papież sam wspomina o wydarzeniu związanym z uwięzieniem go. Por. Martinus I Papa, Epistula 14 [Ad Theodorum], PL 87, 197D - 199A; tenże, Epistula 15 [Ad Theodorum], PL 87, 199B - 202C; tenże, Epistula 16 [Ad quemdam sibi carissimum], PL 87, 201D - 204A.

${ }^{41}$ Por. Narrationes de exilio et morte Sancti Martini, interprete Anastasio Bibliothecario, PL $129,592 \mathrm{C}-594 \mathrm{C}$

${ }^{42}$ Droga do męczeństwa papieża Marcina I została opisana w Narrationes de exilio et morte Sancti Martini, PL 129, 585-604. Por. też J. Śrutwa, Z Rzymu na Krym-męczeńska podróż 
zademonstrować jednoznacznie nadrzędną rolę swych decyzji w stosunku do uchwał podejmowanych w łonie samej administracji kościelnej.

Gdy za cesarza Konstantyna IV (ok. 652-685) wielka część terenów Cesarstwa została definitywnie utracona, a wraz z nimi poza granicami Bizancjum znaleźli się monofizyccy chrześcijanie, nie było już powodu, aby kontynuować religijną politykę na rzecz monoteletyzmu, dzielącego tę część Cesarstwa, która jeszcze pozostała pod władzą Konstantynopola. Wówczas cesarz zdecydował się, by podjać działania na rzecz pojednania Kościoła bizantyńskiego z Rzymem. W tym celu zwołał do Konstantynopola sobór (680-681) ${ }^{43}$, na którym był obecny, a nawet osobiście przewodniczył większości posiedzeń ${ }^{44}$.

Podsumowując należy stwierdzić, że cesarze bizantyńscy, a mianowicie Herakliusz i Konstans II, w kontekście sporów chrystologicznych w VII w. zajęli aktywne stanowisko. Stali się oni promotorami i patronami monoteletyzmu, który miał być kompromisem między monofizytami a zwolennikami Chalcedonu. Ponieważ jednak dyskusja teologiczna została wykorzystana dla celów bieżącej polityki, stała się ona problemem o znaczeniu społeczno-politycznym, a nawet militarnym. Dopiero gdy monoteletyzm utracił swą aktualność polityczna, cesarz Konstantyn IV zdecydował się na zwołanie soboru, którego celem miało być pojednanie z Zachodem. Cesarze więc manipulowali kwestiami i problemami religijnymi w zależności od aktualnej sytuacji geopolitycznej.

2. Podłoże ideologiczne aktywności cesarza. W Bizancjum w VII w., zgodnie jeszcze ze starożytnym zwyczajem ${ }^{45}$, cesarza darzono niezwykłym autorytetem. Istnieją przypuszczenia, że ideologia wyjątkowości osoby cesarza mogła ożywiać się w Bizancjum szczególnie w okresie kryzysów ${ }^{46}$ i konieczności pogłębienia legitymizacji władzy cesarza ${ }^{47}$. W czasie zmagań z Persami

papieża Marcina I, w: J Śrutwa, Studia z dziejów Kościoła w starożytności, Lublin 1999, 142155. Uwięziono także Maksyma Wyznawcę, który trzymał się stanowiska synodu laterańskiego. Maksyma zmuszano do przyjęcia Typosu ze względu na pokój w cesarstwie. W 662 r. potępiono Maksyma, jego ucznia Anastazjusza, papieża Marcina, Sofroniusza Jerozolimskiego i wszystkich tych, którzy wyznawali ich doktrynę. Maksym oraz dwaj jego uczniowie zostali ukarani przez obcięcie języka i prawej ręki. Por. Acta in primo exsilio seu dialogus Maximi XXV, XXVIII, XXXIII, PG 90, 161A, 165B, 169C - 172B.

${ }^{43}$ Por. Concilium Constantinopolitanum III (680), Superscriptio, Mansi XI 201B - 204B. Zob. Stratos, Byzantium in the Seventh Century, t. 4: 668-685, thum. H.T. Hionides, Amsterdam 1978, 115, 119-120 i 131.

${ }^{44}$ Por. Concilium Constantinopolitanum III (680), Actio II, Mansi XI 217B; tamże, Actio III, Mansi XI 221D; tamże, Actio IV, Mansi XI 229B; tamże, Actio V, Mansi XI 316E; tamże, Actio VI, Mansi XI 321C; tamże, Actio VII, Mansi XI 328B; tamże, Actio VIII, Mansi XI 332E; tamże, Actio IX, Mansi XI 377E; tamże, Actio X, Mansi XI 388B; tamże, Actio XI, Mansi XI 455E.

${ }^{45}$ Por. D.J. Geanakoplos, Church and State in the Byzantine Empire: A Reconsideration of the Problem of Caesaropapism, ChH 34 (1965) 384.

${ }^{46}$ Por. A. Kaldellis, The Byzantine Republic: People and Power in New Rome, Cambridge London 2015, 176.

${ }^{47}$ Por. Kaegi, Heraclius: Emperor of Byzantium, s. 62-64. 
było żywe przekonanie o wyjątkowym charakterze osoby cesarza, jako zbawcy chrześcijan w obliczu wroga, który niszczył kościoły i mordował wiernych. Chodziło o osobę cesarza Herakliusza, który był postrzegany jako bohater ${ }^{48}$. Jerzy z Pizydii (ok. 600-631/634), panegirysta Herakliusza, w swym dziele $O$ wyprawie perskiej ${ }^{49}$ często odwoływał się do obrazu cesarza jako człowieka Opatrzności i wysłannika Boga, podobnego do Mojżesza, którego Pan chroni w sposób szczególny ${ }^{50}$. Cesarska propaganda rozwijała i krzewiła te idee, podkreślając szczególnie fakt odzyskania przez cesarza drzewa Krzyża Świętego z rąk Persów oraz podjęty wysiłek w celu zawarcia ugody religijnej, mającej zjednoczyć nowy Izrael w jego wierze w Pana ${ }^{51}$. O utrwaleniu tej idei może świadczyć romans z poł. VII w. Barlaam $i$ Joasaf ${ }^{52}$. Cesarz jest w nim przedstawiany jako przewodnik całkowicie oddany przykazaniom Bożym i miłości Chrystusa, który prowadzi dusze swych poddanych do Boga. Pierwszym zaś zadaniem cesarza jest nauczanie ludzi bojaźni Bożej i sprawiedliwości ${ }^{53}$.

$\mathrm{Z}$ tak zarysowanym obrazem władzy cesarskiej w Bizancjum w VII w. zgadzają się idee propagowane przez zwolenników cesarza w kontekście monoteletyzmu. Przede wszystkim panowało wśród nich przekonanie o kapłańskim autorytecie osoby cesarza. W czasie rozprawy sądowej nad Marcinem I zostały do papieża skierowane następujące słowa: „Występowałeś przeciw cesarzowi [...]. Oto opuściłeś Boga i Bóg cię opuścił" ${ }^{54}$. Występowanie przeciw cesarzowi jest więc równoznaczne $\mathrm{z}$ występowaniem przeciw Bogu. Podobne wnioski można wyprowadzić z rozprawy sądowej nad Maksymem Wyznawcą. Niejaki Grzegorz, jeden z przedstawicieli cesarza, odwołując się

${ }^{48}$ Por. Stratos, Byzantium, t. 3, s. 95; Kaegi, Heraclius: Emperor of Byzantium, s. 296-297.

${ }^{49}$ Georgius Pisida, De expedition Persica, PG 92, 1197A - 1260A.

${ }^{50}$ Szerzej na temat obrazu cesarza u Jerzego z Pizydii, por. M. Whitby, George of Pisidia's Presentation of the Emperor Heraclius and His Campaigns: Variety and Development, w: The reign of Heraclius (610-641): crisis and confrontation, ed. G.J. Reinink - B.H. Stolte, Leuven - Paris 2002, 157-173. Zob. też Pertusi, Il pensiero politico bizantino, s. 66-68; Kaegi, Heraclius: Emperor of Byzantium, s. 116, 183, 192 i 206.

${ }^{51}$ Por. S.A. Spain, Heraclius, Byzantine Imperial Ideology, and The David Plates, „Speculum” 52 (1977) nr 2, 236. Szerzej na ten temat zob. J.W. Drijvers, Heraclius and the "Restitutio Crucis": Notes on Symbolism and Ideology, w: The reign of Heraclius (610-641): crisis and confrontation, ed. G.J. Reinink - B.H. Stolte, Leuven - Paris 2002, 175-190. O odzyskaniu krzyża przez Herakliusza zob. Stratos, Byzantium, t. 1, 248-255.

${ }^{52}$ Grecki tekst utworu mógł być napisany przez mnicha z okolic Jerozolimy w 1. poł. VII w., ale został przez niektórych przypisany także Janowi z Damaszku (Vita Barlaam et Ioasaph, PG 96, $860 \mathrm{~A}-1240 \mathrm{C})$.

${ }^{53}$ Social and Political Thought in Byzantium, s. 81-84. Autorytet władzy w Bizancjum za cesarza Herakliusza został przedstawiony także w sztuce monumentalnej, por. Pertusi, Il pensiero politico bizantino, s. 70 .

${ }^{54}$ Narrationes de exilio et morte Sancti Martini, PL 129, 595B: „Veniensque ad sanctum ac venerabilem virum Martinum apostolicum, dixit ad eum: Vide quomodo Deus te duxit, et tradidit in manus nostras. Tu nitebaris contra imperatorem: quid tibi spei erat? Ecce dereliquisti Deum, et dereliquit te Deus". 
do postaci kapłana i króla Melchizedeka (Rdz 14, 18-19), twierdził, że każdy chrześcijański cesarz jest kapłanem ${ }^{55}$. Zarzucił przy tym Maksymowi, że jego

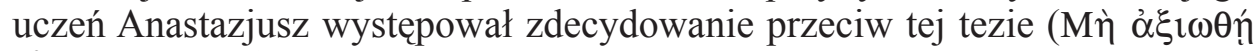

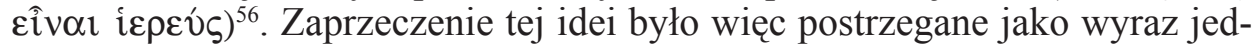
noznacznej wrogości wobec cesarza.

Kapłański autorytet cesarza zakładał, że może on interweniować w sprawy Kościoła i to nawet w kwestiach wiary. Ekthesis wydany przez cesarza, rozpoczyna się następującymi słowami: „Wykład ortodoksyjnej wiary dokonany przez władcę Herakliusza, chronionego przez Boga" ${ }^{57}$. Podobnie na początku Typosu napisano, że cesarz ma zwyczaj troszczyć się o korzyść chrześcijańskiego państwa, a szczególnie o nieskazitelność wiary ${ }^{58}$. To on właśnie rozkazuje poddanym, którzy trwają w ortodoksyjnej i nieskazitelnej wierze, aby nie rozprawiali na temat istnienia dwóch lub jednej woli w Chrystusie ${ }^{59}$. Z kolei syryjski żywot Maksyma Wyznawcy pochwala wydanie Ekthesis, w którym cesarz odrzucił jakoby niegodziwą doktrynę, propagowaną przez Maksyma. Cesarskie rozporządzenie, jak świadczy wspomniany żywot, zostało zaaprobowane przez czterech patriarchów oraz biskupów. Z tego powodu panował pokój do śmierci cesarza Herakliusza ${ }^{60}$. Cesarz więc ma prawo wydawać rozporządzenia $\mathrm{w}$ dziedzinie wiary.

Ponieważ zarówno w Ekthesis ${ }^{61}$, jak i w Typos ${ }^{62}$ cesarz powołuje się na sobory, na natchnionych przez Boga nauczycieli i Ojców oraz stwierdza, że nic nie dodaje ani nie usuwa ze świętych dogmatów, to w ten sposób, niejako siłą tych argumentów, z jednej strony usprawiedliwia siebie, $\mathrm{z}$ drugiej zaś daje do zrozumienia, że nie rości sobie prawa do głoszenie nowej doktryny wiary, lecz wyłącznie do strzeżenia dawnej. Niemniej jednak rezerwował sobie prawo do interpretacji wiary. W Ekthesis zachęca się bowiem wszystkich chrześcijan,

${ }^{55}$ Por. Anastasius Apocrisiarius, Relatio motionis inter Maximum et principles IV, PG 90, 117BC. Por. G. Dagron, Empereur et prêtre: Étude sur le « césaropapisme » byzantine, Paris 1996, 178184. Na temat motywu Melchizedeka w bizantyńskiej myśli politycznej, zob. tamże, s. 187-190.

${ }^{56}$ Anastasius Apocrisiarius, Relatio motionis IV, PG 90, 113D.

${ }^{57}$ Expositio orthodoxae fidei (Ecthesis), ACO II/1, 157, 20-25 (tylko w tekście łacińskim): „Expositio Orthodoxae Fidei facta ab a Deo Conservando et piissimo nostro Domino Magno Principe Heraclio propter emersam ab aliquibus altercationem pro requisitione operationis, consonans in omnibus sanctis et universalibus quinque conciliis. Quam cum multa satisfactione et gratia exciperunt patriarchi(cis) cum sedibus praesules, et gratanter ei consenserunt utpote pacem sanctis Dei Ecclesiis inferente".

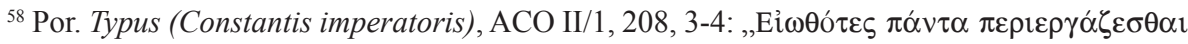

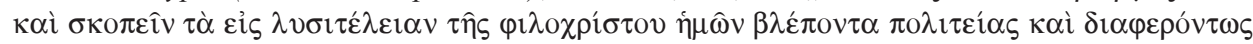

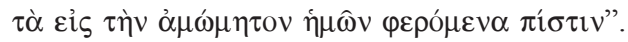

${ }^{59}$ Por. tamże, ACO II/1, 208, 19-25.

${ }^{60}$ Por. Vita Syriaca Maximi Confessoris XV-XVI, ed. S. Brock: An Early Syriac Life of Maximus the Confessor, AnBol 91 (1973) 317.

${ }^{61}$ Por. Expositio orthodoxae fidei (Ecthesis), ACO II/1, 158, 31; tamże, ACO II/1, 160, 33-35; tamże, ACO II/1, 162, 4-5.

${ }^{62}$ Por. Typus (Constantis imperatoris), ACO II/1, 208, 29-31. 
aby myśleli i chwalili Boga zgodnie z cesarską interpretacją Ojców, nic nie dodając i nie ujmując z tego, co natchnieni przez Boga nauczyciele Kościoła wprowadzili dla zbawienia wszystkich wierzących ${ }^{63}$. Poprzez Typos cesarz zobowiązuje więc wszystkich do przyjęcia jego zaleceń w kwestiach wiary, podkreślając przy tym, że ten kto je naruszy zostanie ukarany najpierw przez samego Boga, a następnie przez cesarza. Wyszczególnia też różne hierarchiczne godności osób oraz odpowiadające im kary ${ }^{64}$. Papież Marcin potwierdza powyższe roszczenia cesarza i dodaje $\mathrm{w}$ charakterze komentarza, że w Typosie zostało promulgowane to, w co wszystkie narody chrześcijańskie, w przekonaniu cesarza, powinny uwierzyćc ${ }^{65}$. W ten sposób cesarz rościł sobie prawo do wiążącego wypowiadania się w kwestiach wiary Kościoła powszechnego.

Warto podkreślić, że rozporządzenia cesarza $\mathrm{w}$ dziedzinie doktryny dotyczyły także papieża w Rzymie. Wspomniany Grzegorz, przedstawiciel cesarza, tłumacząc swoją wcześniejszą wizytę w Rzymie, stwierdza, że dobry i wzmocniony przez Boga cesarz zwrócił się do papieża zachęcając go do jedności z patriarchą Konstantynopola ${ }^{66}$. Zjednoczenie to zakładało zaś zaakceptowanie oficjalnego stanowiska Kościoła bizantyńskiego w kwestiach wiary, czyli zaaprobowanie monoteletyzmu.

W związku z tak pojmowaną rolą cesarza w Kościele uważano również, że każdy synod zwołany bez jego zgody nie ma mocy kanonicznej. Biskup Teodozjusz, przedstawiciel cesarza, który miał przekonać Maksyma Wyznawcę do uznania Typosu, stwierdził explicite, że synod rzymski z roku 649 nie ma mocy kanonicznej, ponieważ nie został zwołany przez cesarza ${ }^{67}$.

Na wyżej przedstawionych ideach bazuje przekonanie o absolutnie nadrzędnej roli cesarza $\mathrm{w}$ chrześcijaństwie. $\mathrm{W}$ konsekwencji bycie chrześcijaninem zakładało bezwarunkową wierność cesarzowi. Maksymowi Wyznawcy zarzucono na rozprawie sądowej, że nie jest on chrześcijaninem, ponieważ nienawidzi cesarza ${ }^{68}$. Tę nienawiść wiązano z rzekomą zdradą Egiptu, Aleksandrii, Pentapolis, Tripolis oraz Afryki na rzecz saracenów ${ }^{69}$ i z nieuznaniem

${ }^{63}$ Expositio orthodoxae fidei (Ecthesis), ACO II/1, 162, 7-9.

${ }^{64}$ Por. Typus (Constantis imperatoris), ACO II/1, 210, 6-15.

${ }^{65}$ Por. Martinus I Papa, Epistula 2 [Ad Amandum episcopum], PL 87, 137B-C: „et imperialem typum, sacrilege ausu, totius plenum perfidiae, a clementissimo principe nostro fieri persuasit [Paulus], in quo promulgatum est ut omnes populi Christiani credere debuissent".

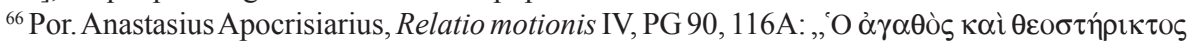

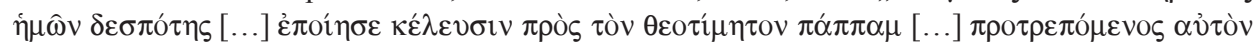

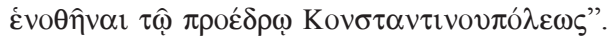

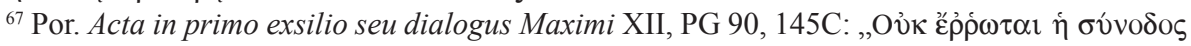

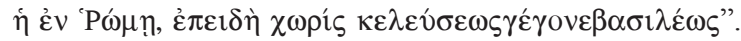

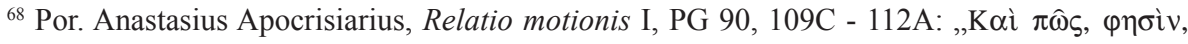

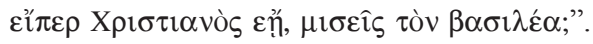

${ }^{69}$ Tamże I, PG 90, 112A-C. Zob. tamże II-III, PG 90, 112C - 113C. 
Typosu. Potępienie bowiem cesarskiego dokumentu było z punktu widzenia zarysowanej wyżej ideologii potępieniem samego cesarza ${ }^{70}$.

Z kolei bycie wrogiem cesarza oznaczało też bycie wrogiem jego państwa jako takiego. Stąd strażnicy uwięzionego papieża Marcina nazywali go heretykiem, buntownikiem, przeciwnikiem Boga oraz człowiekiem, który obala porządek rzymskiego świata ${ }^{71}$. W ideologii bizantyńskiej w VII w. państwo i Kościół traktowano bowiem jako podporządkowaną cesarzowi jedność ${ }^{72}$. Świadczy o tym przytoczone wyżej stwierdzenie z Typosu, że cesarz ma zwyczaj troszczyć się o dobro chrześcijańskiego państwa, a szczególnie o nieskazitelność wiary ${ }^{73}$. Troska o wiarę jest więc integralną częścią polityki cesarskiej.

Ponieważ zaś polityka i religia stanowią jedność, cesarz ma prawo interweniować w kwestiach wiary celem rozwiązania problemów politycznych. Wspomniany Grzegorz, przedstawiciel cesarza, stwierdza, że Typos nakazuje bezwzględne milczenie w celu wprowadzenia pokoju w Cesarstwie ${ }^{74}$. Podobnie czyni biskup Teodozjusz, który przybył do Bizji na miejsce wygnania Maksyma Wyznawcy i tam z jednej strony stwierdza, że Typos został zaakceptowany ze względu na rozporządzenie cesarza, ale nie należy traktować go jako dogmatu ${ }^{75}$, z drugiej zaś, jak zaznaczono, dowodzi, że Typos jest konieczny ze względu na pokój w Cesarstwie ${ }^{76}$. W ten sposób hierarcha ten dał wyraźnie do zrozumienia, że Typos jako dokument dotyczący wiary, ma charakter przede wszystkim polityczny. W ideologii bizantyńskiej w VII w. religia była więc zupełnie podporządkowana dobru państwa.

Podsumowując, należy stwierdzić, że ingerencja cesarzy bizantyńskich w kwestie wiary miała silne podstawy ideologiczne. W ideologii władzy

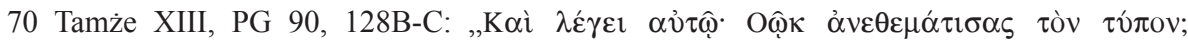

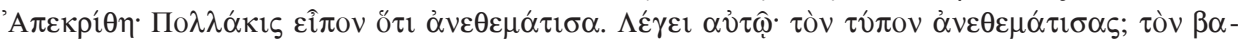

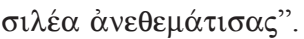

${ }^{71}$ Por. Narrationes de exilio et morte Sancti Martini, PL 129, 592B: „Quas quidem directas species et quantitates custodies bestiales continuo coram eo diripiebant, improperiosa et amara plurima congerentes in eum. Eos autem qui munuscula detulissent injuriis et verberibus afficientes dimittebant, dicentes ad eos: Quoniam quicunque diligitis istum, inimici estis reipublicae. Num quidnam hoc solum ei non valebat inferre dolorem incomparabilem super infirmitatem quae enim aegre deprimebat? Exinde igitur praemittentes ab Avido quemdam custodes qui retinebant eum, nuntiaverunt in Byzantio adventum et captionem ejus, proferentes adversus eum plurima mala: haereticum, et rebellem, Deique adversarium proclamantes, et subvertentem universam terram Romanorum".

${ }^{72}$ Por. Stratos, Byzantium, t. 3, s. 98.

${ }^{73}$ Por. Typus (Constantis imperatoris), ACO II/1, 208, 3-5.

${ }^{74}$ Anastasius Apocrisiarius, Relatio motionis IV, PG 90, 116B: „іv

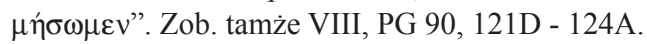

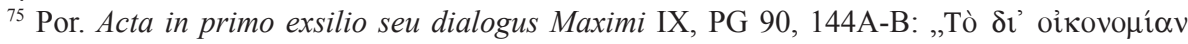

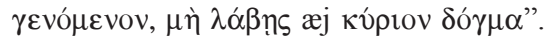

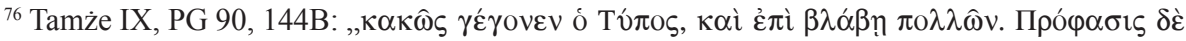

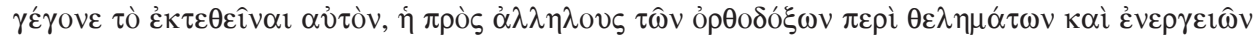

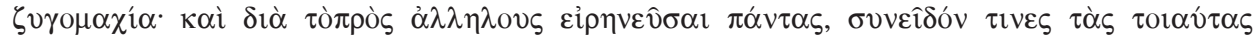

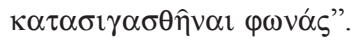


w Bizancjum w VII w. traktowano cesarza jako osobę o kapłańskim autorytecie, a bycie prawdziwym chrześcijaninem zakładało bezwzględną wierność cesarzowi. Z kolei cesarska troska o państwo obejmowała nie tylko zagadnienia społeczno-polityczne, lecz także religijne, które są tym pierwszym ściśle podporządkowane. Powyższa ideologia, jak już zaznaczono, nie została ukształtowana w VII wieku. Jej początków należy szukać już w IV w. W okresie bowiem sporów trynitarnych w Kościele bizantyńskim została utrwalona ariańska doktryna teologiczno-polityczna na temat miejsca cesarza w hierarchicznej strukturze państwa i Kościoła, reprezentowana głównie przez Euzebiusza z Cezarei ${ }^{77}$, a rozpropagowana przez proariańskich biskupów. Doktryna ta legła w Bizancjum u podstaw kształtowania się przyszłych stosunków między Kościołem a państwem ${ }^{78}$. Wyraźne pogłębienie teoria ta znalazła w ideologii władzy głoszonej przez cesarza Justyniana $(527-565)^{79}$.

\section{Recepcja procesarskiej ideologii władzy w Kościele bizantyńskim.} Przekonanie o nadrzędnej roli cesarza w odniesieniu do Kościoła było bardzo rozpowszechnione w Bizancjum w VII w. Ponieważ w Typosie jest wzmianka o tym, że z powodu sporów monoteletycznych prawowierny lud jest w sta-

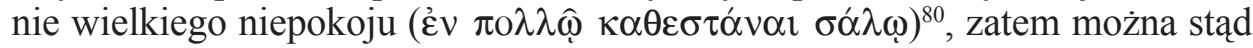
wyprowadzić wniosek, że wielka część wiernych akceptowała założenia doktrynalne propagowane przez cesarza, czyli aprobowała religijny autorytet cesarza. Potwierdzenie przekonania o powszechnym uznaniu autorytetu cesarza znajdujemy we fragmencie protokołu z rozprawy sądowej, w którym napisano, że gdy Maksym Wyznawca zaprzeczył kapłaństwu cesarza, jeden z obecnych na rozprawie, który miał na imię Menas, stwierdził, że mówiąc te rzeczy Maksym dzieli Kościół ${ }^{81}$. Te słowa świadczą o wyraźnych różnicach mentalności chrześcijan dotyczących ideologii władzy cesarskiej w odniesieniu do Kościoła. Chrześcijanom wschodnim trudno bowiem było wyobrazić sobie cesarza nie

77 Por. W. Ceran, Cesarz w politycznej teologii Euzebiusza z Cezarei $i$ nauczaniu Jana Chryzostoma, „Acta Universitatis Lodziensis: Folia Historica” 44 (1992) 13-20; Geanakoplos, Church and State in the Byzantine Empire, s. 384-386. Zob. też J. Canning, A History of Medieval Political Thought: 300-1450, London - New York 1996, 3-5; D.M. Nicol, Byzantine Political Thought, w: The Cambridge History of Medieval Political Thought c. 350-c. 1450, ed. J.H. Burns, Cambridge 2008, 51-55; Kaldellis, The Byzantine Republic, s. 167.

${ }^{78}$ Por. O. Kashchuk, The Attitude of the Pro-Arian Bishops Towards the Emperor in the Period of Reception of the Nicene Christology (325-381), VoxP 34 (2014) t. 61, 143-148 i 154-155; tenże, Втручання імператорів у доктринальні справи церкви в контексті аріанської полеміки $I V$ століття, „Наукові записки Національного університету «Острозька академія», Серія «Історичне релігієзнавство»" 9 (2014) 67-78.

${ }^{79} \mathrm{Na}$ temat koncepcji władzy w prawodawstwie cesarza Justyniana, por. Canning, A History of Medieval Political Thought: 300-1450, s. 5-14: Na temat rozwoju bizantyńskiej politycznej teorii w IV-XIV w., por. Nicol, Byzantine Political Thought, s. 55-79.

${ }^{80}$ Typus (Constantis imperatoris), ACO II/1, 208, 5-6. Por. ACO II/1, 19, 34 - 21, 1; 45, 35-37.

${ }^{81}$ Por. Anastasius Apocrisiarius, Relatio motionis V, PG 90, 117D. 
związanego z ideą kapłaństwa. Nawet przychylnemu Maksymowi Wyznawcy autorowi jego Żywota zanegowanie kapłaństwa cesarza sprawiało trudność ${ }^{82}$.

Ideę o nadrzędnej roli cesarza podnosili szczególnie zwierzchnicy Kościoła obszaru bizantyńskiego, jak już ukazano przy omówieniu aprobowanych przez nich cesarskich dekretów. Papież Marcin I wskazuje na ten fakt, gdy pisze, że monoteleccy przywódcy Kościoła pisali do biskupów Afryki, iż cesarz pobudzony w swym królewskim umyśle i rozsądku wydał sławną i pobożną formułę, w której rozkazuje nie zagłębiać się w szczegóły doktrynalne, traktując je jako rzeczy niewielkiej wagi ${ }^{83}$. Na synodzie w Rzymie w 649 r. przywołano niektóre wypowiedzi Sergiusza z Konstantynopola na rzecz Ekthesis. Sergiusz nazywa Ekthesis wykładem ortodoksyjnego dogmatu, dokonanym przez dzielnego i wielkiego cesarza, ponieważ nauczyła go tego jego mistrzyni - mądrość (por. Mdr 7, 21) ${ }^{84}$. Synod Sergiusza orzekł, że Ekthesis cesarza prawdziwie zgadza się z apostolskim kerygmatem, że współbrzmi ze świętymi i powszechnymi synodami, dogmatami i kanonami oraz że we wszystkim zgadza się z Ojcami, głosicielami ortodoksyjnej wiary ${ }^{85}$. To są, według członków synodu, dogmaty Ojców, czyli opoka Kościoła, umocnienie ortodoksyjnej wiary, symbole pięciu Soborów, utrwalenie jedności ludu chrześcijańskiego, to wreszcie jest spełnieniem idei zbawienia ludzkości ${ }^{86}$. Jeśli ktoś znieważy decyzję dzielnego, wspieranego przez Boga i wielkiego cesarza oraz zwołanego przezeń synodu i będzie nauczał o dwóch albo jednej energii w Chrystusie, to ten, jeśli jest duchownym, zostanie odłączony od posługi, jeśli zaś jest mnichem albo osobą świecka, zostanie odłączony od wspólnoty świętej, Ciała i Krwi Chrystusa (por. Tt 2, 13$)^{87}$.

W podobnym duchu wypowiadał się Cyrus Aleksandryjski w liście do Sergiusza z Konstantynopola. Pisze o Ekthesis jako o wykładzie godnej i pod każdym względem oświeconej wiary, określonej przez chronionego przez Boga cesarza. Tę wiarę, według niego, powinien przyjąć biskup Rzymu, Seweryn. Cesarz troszczy się o przepowiadanie wiary, zarządza słusznie świętymi

${ }^{82}$ Por. Dagron, Empereur et prêtre, s. 181-184.

${ }^{83}$ Por. Martinus I Papa, Epistula 3 [Ad Constantem Imperatorem], PL 87, 143B-C: „In quam ausi sunt religiosis Africae episcopis dicere, scribentes, quod mente consilioque regio vere excitati, memoratam piam formulam exposuistis, praecipientem de nimia observatione paulum sine damno remittere. Haec autem scripserunt sanctis Patribus nullo modo auscultantes, quod in iis quae ad Deum pertinent, inque divinis praedicationibus, id quod parum abest, paulumque mutatum est, non parvum tamen est ducendum. Sed in eo vel maxime vestrae potestati labem, ut dictum est, inurere properarunt in eo quod illam formulam praeter exactam rationem esse testati sunt, et scripto aliis significarunt".

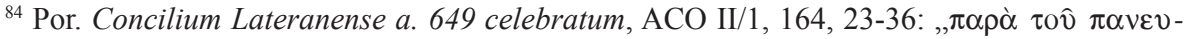

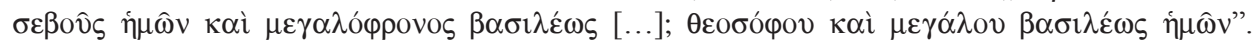
Zob. tamże, ACO II/1, 166, 9-11.

${ }^{85}$ Tamże, ACO II/1, 166, 17-19.

${ }^{86}$ Tamże, ACO II/1, 164, 37 - 166, 5.

${ }^{87}$ Tamże, ACO II/1, 166, 20-30. 
kościołami i strzeże pokoju. Chrystus bowiem ustanowił go także rządcą w sprawach duchowych ${ }^{88}$.

W tym samym duchu wypowiedział się o roli cesarza patriarcha Pyrrus, mówiąc, że cesarz oświeca umysły wierzących, jak ogień oświeca każdą część świata. Pyrrus pisze też, że biskupi we wszystkim przyjmują cesarską wykładnię nauki dogmatycznej i natchnionej przez Boga. Ta wykładnia zgadza się we wszystkim z apostolską Tradycją i pięcioma świętymi soborami. Biskupi, według Pyrrusa, powinni podpisać ortodoksyjny cesarski kerygmat ${ }^{89}$. Podobnie sądzili inni hierarchowie Kościoła wschodniego. Już wspomniany wyżej biskup Teodozjusz, stwierdza, że Typos, nawet jeśli nie odpowiada doktrynie Kościoła, powinien zostać zaakceptowany ${ }^{90}$. Żaden zaś z hierarchów obecnych na zgromadzeniu potępiającym Maksyma Wyznawcę nie powiedział ani słowa w obronie osądzonych ${ }^{91}$. Jak się jednak okaże później, zarysowaną tutaj ideologię władzy cesarskiej przyjmowali nie tylko hierarchowie monoteleccy. Bowiem retoryka Ojców w odniesieniu do osoby cesarza na soborze w Konstantynopolu (680-681) nie różniła się od retoryki biskupów opowiadających się za monoteletyzmem ${ }^{92}$. W ten sposób hierarchowie bizantyńscy dowiedli, że byli głosicielami idei, w myśl której nie było różnicy między świętym a świeckim ${ }^{93}$.

Jest wiele świadectw, które wskazują, że zarówno Ekthesis jak i Typos, chociaż zostały oficjalnie wydane przez cesarzy, były inspirowane głównie, jak to już wcześniej zaznaczono, przez osoby duchowne ${ }^{94}$. Sam zresztą cesarz Herakliusz zaprzeczył swemu autorstwu Ekthesis i przypisał je Sergiuszowi ${ }^{95}$. Świadectwa te potwierdzają tezę, że hierarchowie Kościoła obszaru bizantyńskiego poprzez przekonywanie cesarzy do wydawania dokumentów doktrynalnych, a cesarze przez ich wydanie, głosili otwarcie ideę o kościelnym autorytecie władzy cesarskiej w Bizancjum. Cesarz bowiem usprawiedliwia

\footnotetext{
${ }^{88}$ Tamże, ACO II/1, 172, 9-37.

${ }^{89}$ Tamże, ACO II/1, 168, 8 - 170, 2.

${ }^{90}$ Por. Acta in primo exsilio seu dialogus Maximi IX, PG 90, 144B.

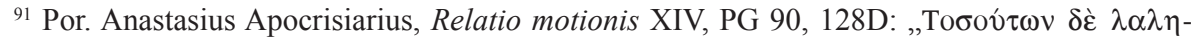

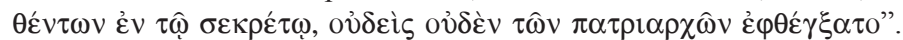

92 Por. Concilium Constantinopolitanum III (680), Actio I, Mansi XI 208E - 209A; tamże, Actio II, Mansi XI 217A-B; tamże, Actio X, Mansi XI 449E; tamże, Mansi XI 452A; tamże, Actio XI, Mansi XI 456D.

${ }^{93}$ Por. Kaldellis, The Byzantine Republic, s. 190-192.

${ }^{94}$ Por. Martinus I Papa, Epistula 3 [Ad Constantem Imperatorem], PL 87, 142C; tenże, Epistula 5 [Ad Joannem Episcopum Philadelphiae], PL 87, 159C-D; tenże, Epistula 2 [Ad Amandum episcopum], PL 87, 137B-C; Concilium Lateranense a. 649 celebratum, ACO II/1, 150, 34-37; tamże, ACO II/1, 206, 20-21; tamże, ACO II/1, 408, 19-21.

${ }^{95}$ Maksym Wyznawca stwierdza, że cesarz Herakliusz napisał, iż Ekthesis to nie jego dzieło, ponieważ on ani nie dyktował go, ani nie zlecał jego kompozycji, natomiast patriarcha Sergiusz skłonił go do tego. Por. Anastasius Apocrisiarius, Relatio motionis I, PG 90, 125A-B. Zob. Concilium Romanum (640), Mansi X 698E - 699A. Na temat autentyczności wypowiedzi Herakliusza, por. Stratos, Byzantium, t. 2, s. 148-149. 
się nie z faktu wydania dokumentu dotyczącego wiary oraz interwencji w kwestie wiary, lecz z kontrowersyjnej treści samego dokumentu.

Nie należy uważać, że wszyscy hierarchowie bizantyńscy w sposób bezwzględny aprobowali poglądy cesarza. Monoteletyzmu bowiem nie należy sprowadzać tylko do doktryny polityczno-teologicznej, gdyż miał on swe głębokie podłoże czysto teologiczne, bowiem u jego źródeł stał prawdziwy problem doktrynalny, który przez cały V i VI w. opierał się na swoistym traktowaniu nauki Cyryla Aleksandryjskiego o hipostatycznej jedności Chrystusa. Dyskusja została więc zapoczątkowana na gruncie teologicznym ${ }^{96}$. Źródeł zaś monoteletyzmu należy doszukiwać się u Teodora Faranity ${ }^{97}$ oraz Temestiusza ${ }^{98}$. Doktryna ta miała zagorzałych zwolenników, wśród których był Cyrus Aleksandryjski i Sergiusz z Konstantynopola ${ }^{99}$. Oprócz przekonań o doktrynalnym autorytecie cesarza mogli więc oni także żywić przekonanie o prawdziwości doktryny monoteletycznej. Gdy jednak cesarz dystansował się od przekonań zwolenników monoteletyzmu, wówczas duchowieństwo potrafiło stawić mu opór. O tym może świadczyć fakt, że, gdy cesarz Konstantyn IV zdecydował się na zwołanie soboru, spotkał się z opozycją duchowieństwa Kościoła Konstantynopolskiego, mieszkańców stolicy i częściowo wojska ${ }^{100}$. Nie całe więc duchowieństwo bizantyńskie sprzyjało idei o doktrynalnym autorytecie cesarza.

Podsumowując, należy stwierdzić, że ideologia dotycząca szczególnej roli władcy w kwestiach wiary została prawie powszechnie przyjęta w Kościele bizantyńskim. Jej zwolennikami stali się przede wszystkim hierarchowie Kościoła. Nie wszyscy jednak w sposób bezwzględny akceptowali ideę kościelnej wyższości cesarza.

$$
* * *
$$

Na podstawie powyższych analiz można stwierdzić, że w dążeniu do zawarcia porozumienia teologicznego w Bizancjum w VII w. cesarze odegrali główną

\footnotetext{
${ }^{96}$ Por. Haldon, Byzantium in the Seventh Century, s. 49; Dagron, Kościót bizantyński, s. 47.

${ }^{97}$ Por. Concilium Lateranense a. 649 celebratum, ACO II/1, 118, 9-11; tamże, ACO II/1, 38,2526. Teodor z Faran (Theodorus Raithenus/Pharanita, ok. 570 - przed 638) - biskup miasta Faran na południowo-zachodnim terenie półwyspu synajskiego. Został potępiony jako krzewiciel monoteletyzmu. Zob. Alexakis, Codex ParisinusGraecus 1115, s. 17; A.J. Ekonomou, Byzantine Rome and the Greek Popes: Eastern Influences on Rome and the Papacy from Gregory the Great to Zacharias, A. D. 590-752, Lanham - Boulder - New York - Toronto - Plymouth 2007, 86-87; Th. Hainhaler, Christ in Christian Tradition, t. II/3: The Churches of Jerusalem and Antioch from 451 to 600, thum. M. Ehrhardt, Oxford 2013, 112-121; D. Larison, Return to Authority: The Monothelete Controversy and the Role of Text, Emperor and Council in the Sixth Ecumenical council, Chicago 2009, 66-67.

${ }^{98}$ Por. Stratos, Byzantium, t. 3, s. 95; Kaegi, Heraclius: Emperor of Byzantium, s. 296-297.

${ }^{99}$ Concilium Lateranense a. 649 celebratum, ACO II/1, 146, 27-29. Patriarcha Sergiusz by1 głównym inspiratorem Herakliusza w jego staraniach w znalezieniu rozwiązania w sprawach religijnych, które dzieliły cesarstwo. Por. Stratos, Byzantium, t. 1, s. 96 i 300.

${ }^{100}$ Por. Stratos, Byzantium, t. 4, s. 115. 119-120 i 131.
} 
rolę. To władcy stymulowali duchowieństwo do prowadzenia dyskusji teologicznej oraz sami wydawali wiążące dokumenty, które miały doprowadzić do kompromisu między monofizytami a zwolennikami Chalcedonu. Cesarze stali się w ten sposób promotorami i patronami kompromisu teologicznego, którego celem było osiagnięcie pokoju w Cesarstwie w obliczu zewnętrznego niebezpieczeństwa. Ponieważ dyskusja teologiczna została wykorzystana w celu politycznym, stała się ona problemem o znaczeniu ogólnospołecznym. Cesarze bowiem manipulowali kwestiami religijnymi, łącząc je z doraźnymi celami politycznymi. Gdy konieczność pojednania się z monofizytami przestała być aktualna, cesarz Konstantyn IV zwołał antymonotelecki sobór do Konstantynopola. Cesarze stali jednak na twardym gruncie ideologicznym, który doktrynalnie wspierał ich działalność. Traktowano ich bowiem jako osoby wybrane, czy wręcz „konsekrowane", które mają niekwestionowane uprawnienia do rozstrzygania problemów Kościoła, nawet w kwestiach wiary. Cesarska troska o państwo obejmowała nie tylko sprawy państwowe, lecz także religijne. Te ideologiczne treści były wspierane przez większość hierarchów Kościoła bizantyńskiego w VII w., choć nie zawsze było to poparcie bezkrytyczne i bezwzględne.

\section{THE ACTIVITY OF THE EMPEROR \\ IN THE CONTEXT OF THE CHRISTOLOGICAL CONTROVERSY IN BYZANTIUM OF THE SEVENTH CENTURY}

\section{(Summary)}

In the quest of theological agreement in Byzantium in the seventh century Emperors played a leading role. The rulers were promoters of the theological discussions and promulgated documents concerning a Christian doctrine obliging all over the Empire. That would lead to a compromise between supporters of both Monophysitism and Chalcedon. The aim of theological compromise was to achieve peace in the Empire in the face of danger. When the necessity for reconciliation with the Monophysites ceased to be valid, Emperor Constantine IV convened the Council in Constantinople, which condemned the adherents of Monotheletism. Emperors had a solid ideological basis for their activities. Emperor was treated as a person with religious authority entitled to intervene in the affairs of the Church, even in matters of faith. His concern for the state included not only the secular affairs, but also religious. Religion is subordinated to state authority. Such ideological contents were supported by majority of the hierarchs of the Byzantine Church in the seventh century. The ideology of the special character of the person of the Emperor was especially alive in Byzantium during various crises.

Key words: emperor, Church, ideology, authority, monotheletism.

Słowa kluczowe: cesarz, Kościół, ideologia, władza, monoteletyzm. 


\title{
BIBLIOGRAFIA
}

\author{
Źródła
}

Acta in primo exsilio seu dialogus Maximi cum Theodosio episcopo Caesareae in Bithynia, PG 90, 136D-172B.

Anastasius Apocrisiarius, Relatio motionis inter Maximum et principles, PG 90, 109C - 129D.

Concilium Constantinopolitanum III, Mansi XI 189A - 922D.

Concilium Lateranense a. 649 celebratum, ed. R. Riedinger, ACO II/1, Berlin 1984.

Expositio orthodoxae fidei (Ecthesis), ed. R. Riedinger, w: Concilium Lateranense a. 649 celebratum, ACO II/1, Berlin 1984, 156, 27 - 162, 13 (secretarius III).

Georgius Pisida, De expeditione Persica, PG 92, 1197A - 1260A.

IoAnnes Damascenus (dubia), Vita Barlaam et Ioasaph, PG 96, 860A - 1240C.

Martinus I PAPA, Epistulae, PL 87, 119D - 204D.

Monophysite texts of the Sixth Century, ed. A. van Roey, Orientalia Lovaniensia Analecta 56, Leuven 1994.

Narrationes de exilio et morte Sancti Martini, interprete Anastasio Bibliothecario, PL 129, $585 \mathrm{C}-604 \mathrm{~A}$.

Sacrorum Conciliorum Nova et Amplissima Collectio, Mansi X-XI.

Satisfactio facta inter Cyrum et eos qui erant ex parte Theodosianorum, Mansi XI 564C-568B.

Social and Political Thought in Byzantium from Justinian I to the last Palaeologus. Passages from Byzantine writers and documents, transl. with an introduction and notes by E. Barker, Oxford 1957.

Typus (Constantis imperatoris), ed. R. Riedinger, w: Concilium Lateranense a. 649 celebratum, ACO II/1, Berlin 1984, 206, 31 - 210, 15 (secretarius IV).

Vita ac certamen Sancti Maximi Confessoris, PG 90, 68A - 109B.

Vita Syriaca Maximi Confessoris, ed. S. Brock: An Early Syriac Life of Maximus the Confessor, AnBol 91 (1973) 299-346.

\section{Opracowania}

Alexakis A., Codex Parisinus Graecus 1115 and It's Archetypes, Dumbarton Oaks Studies 34, Washington 1996.

Canning J., A History of Medieval Political Thought: 300-1450, London - New York 1996.

Ceran W., Cesarz w politycznej teologii Euzebiusza z Cezarei i nauczaniu Jana Chryzostoma, „Acta Universitatis Lodziensis: Folia Historica” 44 (1992) 13-27.

Dagron G., Empereur et prêtre: Étude sur le «césaropapisme» byzantine, Paris 1996.

Dagron G., Kościół bizantyński i chrześcijaństwo bizantyńskie między najazdami a ikonoklazmem (VII wiek - poczqtek VIII wieku), w: Historia chrześcijaństwa. Religia - kultura-polityka, t. 4: Biskupi, mnisi i cesarze 610-1054, red. J.M. Mayer-Ch.I.L. Pietri - A. Vauchez - M. Venard, red. wydania polskiego J. Kłoczowski, Warszawa 1999, 17-85.

Ekonomou A.J., Byzantine Rome and the Greek Popes, Eastern Influences on Rome and the Papacy from Gregory the Great to Zacharias, A. D. 590-752, Lanham - Boulder - New York - Toronto - Plymouth 2007.

Geanakoplos D.J., Church and State in the Byzantine Empire: A Reconsideration of the Problem of Caesaropapism, ChH 34 (1965) 381-403. 
Hainhaler Th., Christ in Christian Tradition, t. II/3: The Churches of Jerusalem and Antioch from 451 to 600, thum. M. Ehrhardt, Oxford 2013.

Haldon J.F., Byzantium in the Seventh Century: The Transformation of a Culture, Cambridge 1997.

Drijvers J. W., Heraclius and the „Restitutio Crucis”: Notes on Symbolism and Ideology, $\mathrm{w}$ : The reign of Heraclius (610-641): crisis and confrontation, ed. G.J. Reinink - B.H. Stolte, Leuven - Paris 2002, 175-190.

Flusin B., Tryumf chrześcijaństwa i określenie prawowierności, w: Świat Bizancjum, t. 1: Cesarstwo wschodniorzymskie 330-641, red. C. Morrisson, tłum. A. Graboń, Kraków 2007, 63-94.

Kaldellis A., The Byzantine Republic: People and Power in New Rome, Cambridge London 2015.

KAEGI W. E., Heraclius: Emperor of Byzantium, Cambridge 2003.

Kashchuк O., The Attitude of the Pro-Arian Bishops Towards the Emperor in the Period of Reception of the Nicene Christology (325-381), VoxP 34 (2014) t. 61, 137-155.

KashchuK O., Втручання імператорів у доктринальні справи церкви в контексті аріанської полеміки $I V$ століття, „Наукові записки Національного університету «Острозька академія», Серія «Історичне релігієзнавство»" 9 (2014) 67-78.

LARISOn D., Return to Authority: The Monothelete Controversy and the Role of Text, Emperor and Council in the Sixth Ecumenical council, Chicago 2009.

Nicol D.M., Byzantine Political Thought, w: The Cambridge History of Medieval Political Thought c. 350-c. 1450, ed. J.H. Burns, Cambridge 2008, 49-79.

Pertusi A., Il pensiero politico bizantino, Il mondo medievale 6, Bologna 1990.

RAHner H., Kościól i państwo we wczesnym chrześcijaństwie, tłum. M. Radożycka - J. Radożycki, Warszawa 1986.

Spain S.A., Heraclius, Byzantine Imperial Ideology, and The David Plates, „Speculum” 52 (1977) nr 2, 217-237.

Stratos A.N., Byzantium in the Seventh Century, t. 1: 602-634, thum. M. Ogilvie-Grant, Amsterdam 1968; t. 2: 634-641, thum. H.T. Hionides, Amsterdam 1972; t. 3: 642-668, thum. H.T. Hionides, Amsterdam 1975; t. 4: 668- 685, thum. H.T. Hionides, Amsterdam 1978.

ŚRutwa J., Z Rzymu na Krym - męczeńska podróż papieża Marcina I, w: J Śrutwa, Studia $z$ dziejów Kościoła w starożytności, Lublin 1999, 142-155.

Whiтву M., George of Pisidia's Presentation of the Emperor Heraclius and His Campaigns: Variety and Development, w: The reign of Heraclius (610-641): crisis and confrontation, ed. G.J. Reinink - B.H. Stolte, Leuven - Paris 2002, 157-173. 